\title{
PENGARUH MODEL PEMBELAJARAN KOOPERATIF TIPE NUMBERED HEADS TOGETHER BERBANTUAN PETA KONSEP TERHADAP HASIL BELAJAR SISWA PADA MATERI POKOK HUKUM HUKUM NEWTON DI KELAS X SEMESTER I SMA NEGERI 1 BATANGTORU
}

\author{
Taufik Aulia Rahmandan Ratna Tanjung \\ Jurusan Fisika FMIPA Universitas Negeri Medan \\ taufik.aulia@gmail.com
}

\begin{abstract}
ABSTRAK
Penelitian ini bertujuan untuk mengetahui hasil belajar siswa menggunakan model pembelajaran koperatif tipe Numbered Head Together (NHT) berbantuan peta konsep terhadap hasil belajar siswa pada materi pokok HukumNewton di kelas X semester I SMA Negeri 1 Batangtoru T.P. 2013/2014. Jenis penelitian ini adalah quasi eksperiment dengan disain two group pretest-posttest. Populasi penelitian adalah seluruh siswa kelas $\mathrm{X}$ Semester I SMA Negeri 1 Batangtoru terdiri dari 6 kelas. Sampel dilakukan dengan cara cluster random sampling mengambil 2 kelas dari 6 kelas, yaitu kelas X-3 sebagai kelas eksperimen dan kelas X-5 kelas kontrol masing-masing berjumlah 39 orang. Instrumen digunakan ada 2 yaitu tes hasil belajar dan lembar observasi. Tes hasil belajar berbentuk pilihan berganda sebanyak 15 soal dengan 5 option yang telah divalidasikan. Uji Hipotesis menggunakan uji t satu pihak. Berdasarkan analisis data diperoleh nilai rata-rata pretes kelas eksperimen adalah 43,93 dengan standar deviasi 13,13 dan kelas kontrol adalah 48,53dengan standar deviasi 13,01. Setelah pembelajaran selesai diberikan, diperoleh postes dengan nilai rata-rata kelas eksperimen 76,41dengan standar deviasi 9,5 dan kelas kontrol 62,1dengan standar deviasi 11,2. Dari hasil pengamatan yang dilakukan oleh observer diperoleh bahwa aktivitas siswa di kelas eksperimen mengalami peningkatan yang positif. Pada pertemuan I ratarata aktivitas siswa sebesar 62,88 , pertemuan II $=72,28$, pertemuan ke III $=74,72$. Hasil uji $\mathrm{t}$ diperoleh $\mathrm{t}_{\text {hitung }}>\mathrm{t}_{\text {tabel }}=5,9>1,67$, sehingga $\mathrm{H}_{\mathrm{o}}$ di tolak Ha diterima dengan kata lain ada pengaruh yang signifikan penggunaan model pembelajaran koperatif tipe Numbered Head Together (NHT) berbantuan peta konsep terhadap hasil belajar siswa pada materi pokok Hukum Hukum Newton di kelas X semester I SMA Negeri 1 Batangtoru T.P. 2013/2014.
\end{abstract}

Kata kunci: Model Pembelajaran NHT (Numbered Heads Together), Hasil Belajar, Aktivitas 


\section{PENDAHULUAN}

Undang-Undang Nomor 20 Tahun 2003 tentang Sistem Pendidikan Nasional menyebutkan, bahwa pendidikan nasional berfungsi mengembangkan kemampuan dan membentuk watak serta peradaban bangsa yang bermartabat dalam rangka mencerdaskan kehidupan bangsa. Pendidikan bertujuan untuk mengembangkan potensi peserta didik agar menjadi manusia yang beriman dan bertakwa kepada Tuhan Yang Maha Esa, berahlak mulia, sehat, berilmu, cakap, kreatif, mandiri, dan menjadi warga negara yang demokratis serta bertanggung jawab (Trianto, 2011).

Sesuai dengan amanat

Peraturan Pemerintah Nomor 19 Tahun 2005 tentang Standar Nasional Pendidikan, salah satu standar yang harus dikembangkan adalah standar tentang proses. Standar proses adalah standar nasional pendidikan yang berkaitan dengan pelaksanaan pembelajaran pada satuan pendidikan untuk mencapai kompetensi lulusan. Standar proses berisi kriteria minimal proses pembelajaran pada satuan pendidikan dasar dan menengah di seluruh wilayah hukum Negara Kesatuan Republik Indonesia (Rusman, 2011).

Masalah yang dihadapi dunia pendidikan adalah masalah lemahnya proses pembelajaran. Dalam proses pembelajaran, anak kurang didorong untuk mengembangkan kemampuan berfikir. Proses pembelajaran di dalam kelas diarahkan kepada kemampuan anak untuk menghafal informasi. Otak anak dipaksa untuk mengingat dan menimbun berbagai informasi tanpa dituntut untuk memahami informasi yang diingatnya tersebut untuk menghubungkannya dengan kehidupan sehari-hari. Akibatnya ketika anak didik lulus dari sekolah mereka pintar secara teoritik tetapi mereka miskin secara aplikasi (Sanjaya 2008).

Pelajaran fisika hingga saat ini masih dianggap sebagai pelajaran yang paling sulit untuk dipahami diantara pelajaran IPA lainnya, pernyataan ini sering dilontarkan oleh siswa SMA. Hal ini dikarenakan mereka merasa selain dituntut untuk memahami konsepkonsep yang ada, juga dituntut untuk mampu menggunakan rumus-rumus fisika. Selain alasan tersebut, siswa juga sering merasa jenuh dan bosan dengan cara-cara mengajar guru yang cenderung lebih memilih cara praktis dengan metode ceramah, sehingga mereka hanya bisa menulis dan mencatat apa yang didengar dan dijelaskan oleh gurunya, tanpa pernah dilibatkan langsung dalam proses menemukan pengetahuan mengembangkan ataupun pengetahuan sendiri. Padahal setiap siswa adalah subjek (pelaku) dalam proses belajar mengajar yangmemiliki keunikan satu sama lain. Ada anak yang cepat tanggap, mudah mengerti, ada pula yang lambat menerima (Siswanto dan Rechana, 2011).

Berdasarkan hasil wawancara dengan salahseorang guru fisika di SMA Negeri 1 Batangtoru, rendahnya hasil belajar siswa tersebut dikarenakan rendahnya hasil belajar siswa mengenai konsep-konsep fisika, serta kurangnya kerja sama di antara siswa untuk mempelajari fisika mengakibatkan menurunnya minat 
belajar terhadap fisika. Hasil belajar siswa yang dicapai pada umumnya kurang mencapai nilai KKM (65). Berdasarkan Daftar Kumpulan Nilai (DKN) siswa kelas X tahun ajaran 2012 - 2013 pada aspek penguasaan dan penerapan konsep serta kerja ilmiah diketahui nilai rata-rata yang diperoleh adalah 65 . Nilai yang dicapai siswa dikategorikan cukup, nilai tersebut tidak murni diperoleh siswa dari hasil kemampuan belajarnya sendiri melainkan sudah ada tambahan dari guru, diantaranya adalah penilaian guru terhadap tugas pribadi, kehadiran siswa, disiplin siswa, dan juga keaktifan siswa pada saat proses balajar mengajar berlangsung (Rahman,2013)

Berdasarkan pemaparan masalah-masalah tersebut di atas, salah satu usaha yang dapat dilakukan oleh guru untuk memperbaikinya adalah dengan pemilihan model pembelajaran yang tepat yaitu pembelajaran yang dapat melibatkan siswa secara aktif sehingga siswa belajar dengan suasana yang menyenangkan, dalam hal ini model pembelajaran yang digunakan adalah model pembelajaran kooperatif. Model pembelajaran kooperatif merupakan suatu pendekatan pembelajaran yang tepat untuk meningkatkan aktivitas siswa selama proses belajar mengajar berlangsung. Model pembelajaran kooperatif yang digunakan dalam penelitian ini adalah tipe Numbered Heads Together (NHT) yang dikembangkan oleh Kagan (Lie, 2004). Model ini memberikan kesempatan kepada siswa untuk saling memberikan ide-ide dan mempertimbangkan jawaban yang paling tepat. Selain itu, model ini juga mendorong siswa untuk meningkatkan semangat kerja sama mereka. Model pembelajaran ini bisa digunakan dalam semua mata pelajaran dan untuk semua tingkatan usia anak didik. Dengan menerapkan model ini,Siswa belajar melaksanakan tanggung jawab pribadinya dan adanya saling keterkaitan dengan rekan-rekan kelompoknya sehingga memudahkan mereka dalam hal pembagian tugas. Dalam model NHT ini ada fase penomoran, sehingga siswa bertanggung jawab atas nomor anggotanya masing.( Lie, 2004)

Menurut hasil penelitian Sitanggang, (2008) diperoleh hasil pembelajaran kooperatif tipe NHT cukup baik, dimana skor nilai ratarata postes siswa sebesar 72,3 serta nilai aktivitas siswa selama proses belajar siswa berlangsung adalah sebesar 77,9 dalam hal ini hasil belajar siswa mengalami kenaikan, dan besar pengaruhnya adalah 8,2 \%. Penelitian yang dilakukan oleh Magdalena (2012) menunjukkan bahwa nilai rata-rata siswa dikelas eksperimen meningkat dari 40,71 menjadi 74,57. Hasil belajar meningkatkan dengan besar pengaruh 16,21\% sehingga model kooperatif tipe NHT ini sangat menarik untuk diterapkan di dalam kelas dalam kegiatan belajar mengajar. Berdasarkan saran dari peneliti Sitanggang dan Magdalena, kendala yang dihadapi dalam penelitian ini adalah sebelum menerapkan model kooperatif tipe NHT, peneliti tidak menciptakan keakraban di dalam kelas terlebih dahulu sehingga siswa kurang aktif dalam pembelajaran karena adnya rasa canggung satu sama lain. Upaya yang akan dilakukan untuk 
mengatasi kendala dalam penelitian ini adalah menciptakan suasana keakraban di dalam kelas terlebih dahulu dengan cara memperkenalkan diri kepada siswa dan meminta siswa untuk memperkenalkan diri juga dan setelah itu memberikan motivasi kepada siswa dalam bentuk ilustrasi ataupun cerita. Selain itu, setiap pembelajaran berikutnya anggota kelompok berganti dengan yang lain sehingga akan lebih mengakrabkan mereka satu sama lain.

Berdasarkan uraian di atas maka peneliti ingin melakukan penelitian dengan tujuan untuk mengetahui hasil belajar siswa menggunakan model pembelajaran koperatif tipe Numbered Head Together (NHT) berbantuan peta konsep terhadap hasil belajar siswa pada materi pokok HukumNewton di kelas X semester I SMA Negeri 1 Batangtoru T.P. 2013/2014.

\section{METODE PENELITIAN}

Penelitian ini telah dilaksanakan di SMA Negeri 1 Batangtoruyang beralamatkan di Jalan Merdeka Kecamatan Batangtoru Kabupaten Tapanuli Selatan, waktu penelitian dilaksanakan Pada semester I Tahun Ajaran 2013/2014. Populasi penelitian ini adalah seluruh SiswaSiswi Kelas X Semester I SMA Negeri 1Batangtoru Tahun Ajaran 2013/2014 yang terdiri dari 6 kelas dan setiap kelas masing-masing 39 siswa. Penelitian ini melibatkan dua kelas yang diberi perlakuan yang berbeda, dimana kelas eksperimen menggunakan model pembelajaran kooperatif tipe NHT dan kelas kontrol menggunakan model pembelajaran konvensional.Sebelum melakukan pembelajaran peneliti memberikan tes awal (pre-tes) kepada kelas eksperimen dan kelas kontrol. Desain penelitian ini pretest-posttest control group design Rancangan penelitian ini ditunjukkan pada Tabel 1.

Tabel 1. Rancangan Penelitian

\begin{tabular}{|l|c|c|c|}
\hline \multicolumn{1}{|c|}{ Kelas } & $\begin{array}{c}\text { Pre- } \\
\text { tes }\end{array}$ & Perlakuan & $\begin{array}{c}\text { Post- } \\
\text { tes }\end{array}$ \\
\hline Eksperimen & $\mathrm{T}_{1}$ & $\mathrm{X}_{1}$ & $\mathrm{~T}_{2}$ \\
\hline Kontrol & $\mathrm{T}_{1}$ & $\mathrm{O}$ & $\mathrm{T}_{2}$ \\
\hline
\end{tabular}

\section{Keterangan:}

$\mathrm{T}_{1}=$ Tes awal (Pre-tes)

$\mathrm{T}_{2}=$ Tes akhir (Post-tes)

$\mathrm{X}_{1}=$ Model pembelajaran

kooperatif tipe NHT

$\mathrm{O}=$ model konvensional

$$
\text { Uji hipotesis }
$$

yang

dikemukakan dilaksanakan dengan membandingkan rata-rata skor hasil belajar yang dicapai baik kelas eksperimen maupun kelas kontrol. Data yang diperoleh ditabulasikan kemudian dicari rata-ratanya. Sebelum dilakukan penganalisisan data, terlebih dahulu ditentukan skor masing-masing kelompok sampel lalu dilakukan pengolahan data dengan langkah-langkah sebagai berikut:

a) Menghitung nilai rata-rata dan simpangan baku

b) Uji Normalitas

c) Uji Homogenitas

Uji normalitas dan uji homogenitas dimaksudkan sebagai prasyarat melakukan uji hipotesis jika data terdistribusi normal dan homogen.

d) Pengujian Hipotesis (Uji t)

Uji $t$ dua pihak digunakan untuk mengetahui kesamaan kemampuan awal siswa pada kedua kelompok sampel.

kemampuan awal yang berbeda.

Data penelitian yang terdistribusi normal dan homogen dilanjutkan dengan menguji 
hipotesis menggunakan uji beda dengan rumus(Sudjana, 2005 :239) :

$$
t_{\text {hitung }}=\frac{\overline{X_{1}}-\overline{X_{2}}}{S \sqrt{\left(\frac{1}{n_{2}}\right)+\left(\frac{1}{n_{2}}\right)}}
$$

Analisis data yang menunjukkan bahwa, $-t_{1-\frac{1}{2} \alpha}<$ $t<t_{1-\frac{1}{2} \alpha}$ maka hipotesis Ho diterima, berarti kemampuan awal siswa pada kelas kontrol sama dengan kemampuan awal siswa pada kelas Eksperimen. Dan jika analisis data menunjukkan harga $\mathrm{t}$ yang lain, maka Ho ditolak diterima $\mathrm{Ha}$, berarti kemampuan awal siswa pada kelas eksperimen tidak sama dengan kemampuan awal siswa pada kelas kontrol.

Uji t satu pihak digunakan untuk mengetahui pengaruh dari suatu perlakuan yaitu model pembelajaran Numbered Heads Togetherberbantuan peta konsep terhadap hasil belajar siswa.

Data penelitian yang terdistribusi normal dan homogen dilanjutkan dengan menguji hipotesis menggunakan uji $t$ dengan rumus, yaitu:

$$
t=\frac{\overline{X_{1}}-\overline{X_{2}}}{S \sqrt{\frac{1}{n_{1}}+\frac{1}{n_{2}}}}
$$

Jika analisis

data menunjukkan bahwa, $t>t_{1-\alpha}$ atau nilai $\mathrm{t}$ hitung yang dipeoreh lebih dari $t_{1-\alpha}$, maka hipotesis Ho ditolak dan $\mathrm{Ha}$ diterima. Dapat diambil kesimpulan hasil belajar siswa pada kelas eksperimen lebih besar daripada hasil belajar siswa kelas kontrol, maka model pembelajaran Numberd Heads Together berbantuan peta konsep berpengaruh terhadap hasil belajar siswa.

\section{HASIL DAN PEMBAHASAN}

Adapun hasil penelitian dengan nilai rata-rata pretes kelas eksperimen sebesar 43,90 dan kelas kontrol sebesar 51,1. Sedangkan setelah diberikan perlakuan yang berbeda dimana pada kelas eksperimen diberikan pembelajaran dengan model Numbered Heads Togetherberbantu peta konsep dan pada kelas kontrol diberikan pembelajaran Konvensional, diperoleh bahwa rata-rata postes kelas eksperimen sebesar 76,4 dan rata-rata postes kelas kontrol sebesar 62,1. Dari hasil perhitungan diperoleh suatu kesimpulan bahwa kemampuan awal siswa kelas eksperimen dan kelas kontrol adalah homogen. Demikian pula untuk uji normalitas dan uji homogenitas, perolehan nilai hasil pretes dan postes untuk kelas eksperimen dan kelas kontrol tersebut sudah normal dan homogen.

Dari analisis data uji hipotesis (uji t satu pihak) ternyata diperoleh $\mathrm{t}_{\text {hitung }}=5,9$ dan $\mathrm{t}_{\text {tabel }}=1,67$ dengan $\mathrm{a}$ $=0,05$ maka hal ini menyatakan bahwa thitung $>t_{\text {tabel }}$ atau 5,9 $>1,67$ yang artinya $\mathrm{H}_{\mathrm{a}}$ diterima dan $\mathrm{H}_{\mathrm{o}}$ ditolak. Sehingga dapat diartikan bahwa ada pengaruh model pembelajaran koopertif tipe NHT terhadap hasil belajar siswa di kelas eksperimen.

Dari hasil pengamatan yang dilakukan oleh observer diperoleh bahwa aktivitas siswa di kelas eksperimen mengalami peningkatan dari pertemuan pertama hingga pertemuan ketiga. Pada pertemuan pertama nilai rata-rata aktivitas siswa diperoleh sebesar 62,88, pertemuan kedua diperoleh nilai rata-rata 72,28 , dan pertemuan ketiga diperoleh nilai rata-rata 
74,72 terjadi peningkatan aktivitas siswa dalam belajar. Hal ini dapat diartikan bahwa siswa sudah dapat mengikuti dan mulai tertarik dengan pembelajaran koopertif tipe NHTsehingga dapat dikatakan bahwa model pembelajaran Numbered Heads Together berbantu peta konsep memberikan pengaruh yang signifikan terhadap hasil belajar siswa pada materi pokok Hukum-hukum Newton di kelas X semester I SMA Negeri 1 Batangtoru.

Secara lebih terperinci, data nilai pretes kedua kelas dapat digambarkan dalam diagram batangpada Gambar 1.

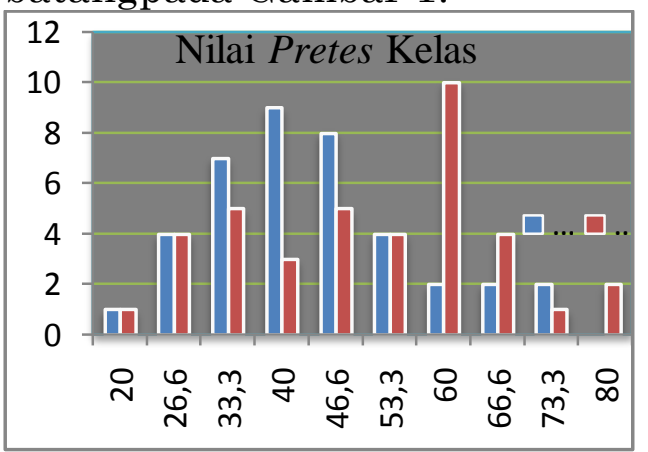

Gambar 1. Diagram Batang Nilai Pretes Kelas Eksperimen dan Kontrol

Perbandingan nilai postes kelas Eksperimen dan kelas kontrol dapat dilihat dalam diagram batang pada Gambar 2.

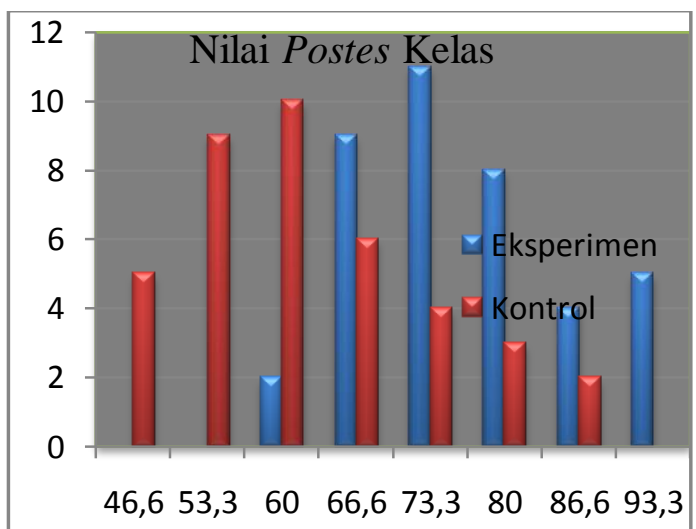

Gambar 2. Diagram Batang Nilai Postes Kelas Eksperimen dan Kontrol
Uji normalitas data pretes dan postes kelas eksperimen dan kelas kontrol menggunakan uji liliefors, setelah dilakukan pengujian maka data pretes dan postes kedua kelas terdistribusi normal. Uji homogenitas pretes dan postes kelas eksperimen dan kelas kontrol menggunakan uji kesamaan dua varians. Berdasarkan hasil pengujian ini data kedua kelompok sampel dinyatakan homogen sehingga layak dilakukan uji hipotesis dengan hasil uji hipotesis sebagai berikut:

Tabel 2.Ringkasan Perhitungan Uji t Pada Postes

\begin{tabular}{|c|l|c|c|c|c|}
\hline No & \multicolumn{1}{|c|}{ Sampel } & $\begin{array}{c}\text { Rata- }^{\text {rata }} \\
\text { rat }\end{array}$ & $\begin{array}{c}\text { thi }_{\text {tung }} \\
\text { tutabel }\end{array}$ & $\begin{array}{c}\text { Kesim } \\
\text { pulan }\end{array}$ \\
\hline 1 & K.Eksperimen & 76,4 & & & $\begin{array}{c}\text { Terda } \\
\text { pat } \\
\text { Perbeda } \\
\text { an }\end{array}$ \\
\hline
\end{tabular}

Dengan perhitungan data menggunakan uji hipotesis (uji $t$ satu pihak) ternyata diperoleh $t_{\text {hitung }}=5,9 \mathrm{dan} \mathrm{t}_{\text {tabel }}=1,67$ dengan $\mathrm{\alpha}$ $=0,05$ maka hal ini menyatakan bahwa thitung $>t_{\text {tabel }}$ atau 5,9>1,67 yang artinya $\mathrm{H}_{\mathrm{a}}$ diterima dan $\mathrm{H}_{\mathrm{o}}$ ditolak. Sehingga dapat diartikan bahwa ada pengaruh model pembelajaran koopertif tipe NHT terhadap hasil belajar siswa di kelas eksperimen.

Dari hasil pengamatan yang dilakukan oleh observer diperoleh bahwa aktivitas siswa di kelas eksperimen mengalami peningkatan dari pertemuan pertama hingga pertemuan ketiga. Pada pertemuan pertama nilai rata-rata aktivitas siswa diperoleh sebesar 62,88. Pada pertemuan kedua diperoleh peningkatan yang positif terhadap aktivitas siswa dengan nilai ratarata 72,28. Hal ini menunjukkan siswa mulai dapat mengikuti 
pembelajaran menggunakan model NHT. Dan pada pertemuan ketiga juga diperoleh peningkatan terhadap aktivitas siswa dengan nilai rata-rata 74,72. Hal ini dapat diartikan bahwa siswa sudah dapat mengikuti dan mulai tertarik dengan pembelajaran koopertif tipe NHT.

Pembelajarandengan

menggunakan model kooperatif tipe NHT memiliki kelebihan dibandingkan dengan pembelajaran konvensioanl. Pada pembelajaran model kooperatif tipe NHT dapat memacu dan merangsang siswa untuk aktif dalam proses belajar mengajar. Pembelajaran model kooperatif tipe NHT dapat meningkatkan kemampuan siswa dalam berfikir dan juga meningkatkan rasa ingin tahu siswa, serta rasa tanggungjawab terhadap kelompoknya. Sehingga menjadikan siswa lebih termotivasi untuk belajar sebab siswa diajak terlibat langsung dalam proses pembelajaran.

Namun disamping kelebihan tersebut, model pembelajaran kooperatif tipe NHT juga memiliki kelemahan yang menyebabkan pencapaian hasil belajar belum maksimal dan peningkatan hasil belajar masih tergolong rendah, kelemahan tersebut antara lain: 1) kerjasama kelompok sering kali hanya melibatkan siswa yang mampu sebab mereka cukup memimpin dan mengarahkan siswa yang kurang mampu; 2) keterbatasan peneliti dalam mengalokasikan waktu pada saat siswa mengajukan hasil diskusi mereka shingga tidak semua anggota kelompok dapat mengajukan hasil diskusi mereka; 3) kondisi kelas yang menggunakan pembelajaran kooperatif tipe NHT sulit untuk dikontrol sebab kesempatan diskusi dalam proses belajar memberi peluang bagi siswa untuk ribut.

\section{KESIMPULAN}

Berdasarkan hasil penelitian yang diperoleh dari hasil analisa data dan pengujian hipotesis maka dapat disimpulkan sebagai berikut:

1. Hasil belajar fisika siswa yang diberi model pembelajaran kooperatif tipe Numbered Heads Together (NHT) pada materi pokok pa Hukum-hukum Newton di kelas X SMA Negeri1 Batangtoru T.A 2013/2014 dengan rata-rata sebesar 76,4.

2. Hasil belajar fisika siswa yang diberi model pembelajaran Konvensional pada materi Hukum-hukum Newton di kelas SMA Negeri1Batangtoru T.A 2013/2014 dengan rata-rata sebesar 62,1 .

3. Aktivitas siswa selama mengikuti pembelajaran dengan menggunakan model pembelajaran kooperatif tipe NHTpada materi Hukumhukum Newton di kelas X SMA Negeri 1 Batangtoru T.A 2013/2014 diperoleh rata-rata skor aktivitas siswa pada ketiga pertemuan mencapai 14,9 dan persentase $71 \%$ dengan kategori nilai aktivitas siswa cukup baik.

4. Ada pengaruh model pembelajaran kooperatif tipe NHT dengan model pembelajaran konvensional pada materi Hukum-hukum Newton di kelas X SMA Negeri I Batangtoru T.A 2013/2014 dengan nilai $t_{\text {hitung }}>t_{\text {tabel }}=(5,9>$ 1,67). Besar persentase peningkatan hasil belajar 
karena pengaruh perlakuan model pembelajaran NHTadalah23 \%.

\section{SARAN}

Berdasarkan hasil dan kesimpulan dalam penelitian ini, maka peneliti mempunyai beberapa saran, yaitu :

1. Pada penelitian ini sebaiknya pengelompokkan siswa disesuaikan dengan kemampuan setiap siswa, agar setiap kelompok diskusi homogen.

2. Bagi peneliti selanjutnya disarankan sebelum memulai penelitian terlebih dahulu dijelaskan kepada siswa bagaimana langkah-langkah pelaksanaan pembelajaran koopertif tipe Numbered Heads Together (NHT), sehingga ketika proses pembelajaran berlangsung para siswa sudah mengerti apa yang akan dilakukan dan tidak menyita waktu untuk langkah-langkah pembelajaran selanjutnya.

3. Kepada peneliti selanjutnya yang ingin melakukan penelitian yang sama disarankan agar membuat soal LKS yang jawabannya tidak terlalu panjang, sehingga ketika berdiskusi dan mempresentasikan jawaban tidak menyita waktu dan semua kelompok dapat berpartisipasi dalam diskusi.

4. Bagi para peneliti selanjutnya yang ingin meneliti dengan model yang sama disarankan lebih dapat mengkoordinir semua kelompok agar diskusi yang dilakuan berjalan lancar.

\section{DAFTAR PUSTAKA}

Abdurahman, M. (2003), Pendidikan Bagi Anak Berkesulitan Belajar. Jakarta : Rineka Cipta

Anisabitah, Nur., (2012), Penerapan Model Pembelajaran Kooperatif Tipe NHT(Numbered Heads Together) dengan Metote Make A Match terhadap Hasil Belajar Siswa pada Materi Alat Optik di MTs NU Trate Gresik, Jurnal pendidikan matematika dan sains ISSN: 1907-7157.

Arikunto, S. (2009),Dasar-dasar Evaluasi Pendidikan. Jakarta :

Bumi Aksara

Arikunto, S. (2006),Prosedur

Penelitian. Jakarta : Rineka

Cipta

Dahar, R, W. (2003), Teori-teori

Belajar, Jakarta: Gelora Aksara

Prima.

Dormatio., 2013.

http://dormatio.blogspot.com/201

3/01/model-pembelajaran-

konvensional.html (Diakses Juni 2013).

Hudoyo, Herman. (1988).

Pengembangan Kurikulum

Matematika dan

Pelaksanaannya di depan Kelas. Surabaya: Usaha Nasional.

Isjoni, (2009), Cooperative Learning, Bandung: Alfabeta

Kanginan, M. (2007), Fisika Untuk $S M A$ Kelas $X$. Jakarta : Erlangga

Lie, A., (2008).Cooperative Learning Mempraktikkan Cooperative Learning Di Ruang-Ruang Kelas. Jakarta : PT Grasindo

Manullang, Magdalena, (2012). Pengaruh Model Pembelajaran Kooperatif Tipe Numbered Head Together Terhadap Hasil Belajar Siswa Pada Materi Listrik Statis diKelas IX Semester I SMP Swasta 
GKPIPadang Bulan Medan T. P. 2010 / 2011., Skripsi, FMIPA, Unimed, Medan.

Mediafunia., 2013. http://mediafunia.blogspot.com/2 013/01/model-pembelajarankonvensional.html (Diakses Juni 2013)

Rusman., 2011. Model-Model Pembelajaran. Jakarta: PT. Raja Grafindo Persada

Sanjaya, Wina, (2006), Strategi Pembelajaran. Bandung : Kencana

Sembiring, S, Mulyana. (2009), Pengaruh Model pembelajaran kooperatif tipe NHT terhadap hasil belajar siswa pada materi pokok kalor di kelas VII semester I SMP Negeri 2 Kaban jaheT.A. 2009/2010., Skripsi, FMIPA, Unimed, Medan.

Sitanggang, (2008). Pengaruh Model pembelajaran kooperatif tipe NHT terhadap hasil belajar siswa pada materi pokok kalor di kelas VII semester I SMP Negeri 1 Batang KuisT.A. 2009/2010., Skripsi, FMIPA, Unimed, Medan.

Situmorang, M, (2009).Buku Pedoman Penulisan Skripsi Mahasiswa Operasional danStandar Kepembimbingan Skripsi, Unimed, Medan.

Slameto, (2003), Belajar dan FaktorFaktor Yang Mempengaruhinya. Jakarta : Rineka Cipta

Slavin, Robert E, (2005). Cooperative Learning, Theory, Research and practice, London,Allyn dan Bacon.

Sudjana, N. (2009). Penilaian Hasil Proses Belajar Mengajar. Bandung: PT. Remaja Rosdakarya
Sudjana, (2005), Metoda Statistika. Bandung : Tarsito

Suprijono, A. (2009), Cooperative Learning. Surabaya : Pustaka Pelajar

Trianto. (2009).Mendesain Model Pembelajaran Inovatif-Progresif. Kencana, Jakarta. 